\title{
Analysis of the effects of pesticides and nanopesticides on the environment
}

\author{
Caroline Nishisaka ${ }^{1 *}$, Renato Grillo ${ }^{2}$, Gabriela Sanches ${ }^{3}$, Leonardo Fraceto ${ }^{4}$, Renata Lima ${ }^{1}$ \\ From 5th Congress of the Brazilian Biotechnology Society (SBBIOTEC) \\ Florianópolis, Brazil. 10-14 November 2013
}

One of the main consequences of population growth is that an equivalent food production increase is needed. To meet this basic need of society and ensure growth in food production, it is necessary the use of agrochemicals such as herbicides, preventing competition between crops and weeds for soil nutrients. This growth in use of agrochemicals has historically had undesirable consequences due to their indiscriminate and sometimes reckless use, with health problems for farmers and environmental damage. One of the possible solutions to increase agricultural production without these consequences would be the application of nanotechnology to allow a safer use of pesticides and lessen health and environmental side-effects. However, the use of nanotechnology demands an investigation of possible toxic effects of this technology, mainly in relation to contamination of soil and water. The study we performed aimed to produce nanoparticles containing the herbicide paraquat and to analyze its possible genotoxic effects. The technique used was cytogenetic test of Allium cepa treated with nanoparaquat, conventional paraquat, tripolyphosphate chitosan nanoparticles, which were made in duplicate with and without humic substances. All concentrations were $0,38 \mathrm{mg} \cdot \mathrm{mL}^{-1}$, and negative control was made with ultrapure water and humic substances for comparative purposes. Initial results indicated less chromosome damage in nanoparaquat treated samples compared to conventional paraquat herbicide, indicating that nanoencapsulation is a viable option as an attempt to minimize damage caused by paraquat.

\section{Authors' details \\ 'Biotechnology, University of Sorocaba, Sorocaba, SP, Brazil. ${ }^{2}$ Graduate in Functional and Molecular Biology, State University of Campinas, Campinas, SP, Brazil. ${ }^{3}$ Bioprocess and Biotechnology Engineering, University of}

${ }^{1}$ Biotechnology, University of Sorocaba, Sorocaba, SP, Brazil

Full list of author information is available at the end of the article
Sorocaba, Sorocaba, SP, Brazil. ${ }^{4}$ State University of São Paulo, Sorocaba, SP, Brazil.

Published: 1 October 2014

References

1. Larini L: Toxicologia dos Praguicidas. In In Toxicologia dos Praguicidas. Volume 1.. 1 edition. São Paulo: Manole Ltda;Manole Ltda 1999:136-137.

2. Fiskesjö G: The Allium test as a standard in environmental monitoring. Hereditas 1985, 102(1):99-112

3. Rocha JC, Rosa AH: Importância das Substâncias Húmicas no Ambiente. In Substâncias húmicas aquáticas: Interação com espécies metálicas. Volume 1.. 1 edition. São Paulo: Editora Unesp;Rocha JC 2003:37-39.

\section{doi:10.1186/1753-6561-8-S4-P100}

Cite this article as: Nishisaka et al:: Analysis of the effects of pesticides and nanopesticides on the environment. BMC Proceedings 2014 8(Suppl 4):P100.
Submit your next manuscript to BioMed Central and take full advantage of:

- Convenient online submission

- Thorough peer review

- No space constraints or color figure charges

- Immediate publication on acceptance

- Inclusion in PubMed, CAS, Scopus and Google Scholar

- Research which is freely available for redistribution
() Biomed Central
() Bïomed Central

(c) 2014 Nishisaka et al.; licensee BioMed Central Ltd. This is an Open Access article distributed under the terms of the Creative Commons Attribution License (http://creativecommons.org/licenses/by/4.0), which permits unrestricted use, distribution, and reproduction in any medium, provided the original work is properly cited. The Creative Commons Public Domain Dedication waiver (http://creativecommons.org/publicdomain/zero/1.0/) applies to the data made available in this article, unless otherwise stated. 